\title{
Verzugsoptimierung durch Schweißsimulation in komplexen Baugruppen für Lkw-Sonderfahrzeuge
}

Dr. Hendrik Schafstall, simufact engineering gmbh

Zum Zeitpunkt der Drucklegung lagen diese Unterlagen noch nicht vor. Wir bitten um Verständnis. 